\title{
An Implication of Spectral Interference of Praseodymium on Trace Metal Assay by Capacitively Coupled Device-based ICP-AES
}

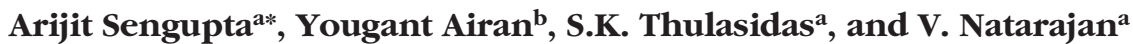 \\ ${ }^{a}$ Radiochemistry Division, Bhabha Atomic Research Centre, Trombay, Mumbai, India \\ ${ }^{b}$ Chemistry Department, Hindu College, University of Delhi, Delhi, India
}

\section{INTRODUCTION}

The atomic emission spectroscopic technique is a simultaneously multi-elemental with acceptable merits of analytical perform-ance and is routinely used in the trace level determination of different analytes (1-5). Spectral interference from emission-rich matrix elements on the determination of analytes at trace level is one of the major problems faced by researchers (6-10). To suppress the spectral interference, the emission-rich matrix element is preferentially separated from the trace analytes either physically using the d.c. arc carrier distillation technique utilizing the differences in the volatilization characteristics (11-14), or chemically by selective extraction of the emission-rich matrix element from analytes using a suitable ligand system followed by analysis of the raffinate (15-21). Even though the d.c. arc technique is advantageous due to its simplicity, requiring less sample handling and less time, it suffers from poor precision due to arc wandering (22-23). In addition, ICPAES requires a selective extractant for almost quantitative separation of the major matrix without loss of the constituents even at trace levels. This involves more handling of the samples and a sufficiently large time for sample preparation including dissolution of the solid samples, feed conditioning, separation, etc. Moreover, it is very challenging for preferential separation of one rare earth element (REE) from other rare earths, especially when the aim is

\footnotetext{
*Corresponding autbor.
}

E-mail: arijita@barc.gov.in

\section{ABSTRACT}

An attempt was made to understand the spectral interference of $\mathrm{Pr}$ on 27 analytes (Ag, Ba, $\mathrm{Bi}, \mathrm{Cd}, \mathrm{Cr}, \mathrm{Cu}, \mathrm{Dy}, \mathrm{Li}, \mathrm{Mg}, \mathrm{Mn}$, $\mathrm{Na}, \mathrm{Nd}, \mathrm{Sr}, \mathrm{Zn}, \mathrm{Ca}, \mathrm{B}, \mathrm{Co}, \mathrm{Fe}, \mathrm{Ga}$, $\mathrm{La}, \mathrm{Ni}, \mathrm{Tl}, \mathrm{Ce}, \mathrm{Pb}, \mathrm{Al}, \mathrm{Gd}$, and In) using a capacitively coupled device (CCD)-based detector system with ICP-AES. The present study includes identification of suitable interference-free analytical lines of these analytes, evaluation of correction factor of each analytical line, determination of tolerance levels of Pr on these analytical lines along with the analytical performance of these lines (i.e., detection limits, sensitivity, linear dynamic range, precession, etc.) in the presence of a Pr matrix. Based on the spectral interference as well as the analytical performance study, a new approach for the direct ICP-AES determination of these analytes at trace levels without chemical separation was adopted. This method was found to be simple, precise, sensitive, and less time-consuming. The developed methodology was validated using synthetic samples prepared from commercially available standard reference material solutions of individual elements with satisfactory results. The method was also compared with the other existing techniques.

to determine the trace rare earth elements in other rare earth matrices. Thus, it appears to be attractive to determine trace constituents including rare earth elements in one of the rare earths, i.e., a $\mathrm{Pr}$ matrix, by ICP-AES without requiring physical/chemical separation.
To serve the above purpose, a systematic study of the spectral interference of Pr on the analytes is required. Several attempts were made to understand the spectral interference of the rare earth element on other rare earths by ICPAES using a photomultiplier tubebased detection system (24-28). Due to the advancements of the capacitatively coupled device (CCD)-based detection system in ICP-AES, the choice of alternative analytical lines of the elements, increases, which is of great significance in a situation when the best analytically performed line of an analyte is significantly interfered by the emission-rich matrix element.

In this work, a systematic study was carried out to understand the spectral interference of $\mathrm{Pr}$ on different analytes, including some of the rare earth elements. An ICP-AESbased method for the determination of these analytes in a Pr matrix is presented without requiring any separation. The method was validated using synthetic samples prepared from commercially available standard reference materials of the individual elemental solution. Moreover, the methodology was also compared with other analytical techniques.

\section{EXPERIMENTAL}

\section{Instrumental and Operating Conditions}

The analysis was carried out using a Model Arcos FHS12 ICP-AES (Spectro-Arcos, Germany) with a high-performing capacitively coupled device (CCD) as the detector and inductively coupled plasma as the excitation source. The instru- 
mental operating conditions and specifications are listed in Table I. The detector system, consisting of linear arrays of the CCD detector (3648 pixels/array), thermally stabilized together with the optical system, provides the ability to choose alternate analytical lines.

\section{Standard Solutions and Reagents}

Standard solutions for the elements were prepared from Certipur ${ }^{\circledR}$ ICP standard solutions, which are also the standard reference material solution of the individual elements (E-Merck, Darmstadt, Germany) by proper dilution. Suprapur® ${ }^{\circledR} \mathrm{HNO}_{3}$ (E-Merck, Darmstadt, Germany) and quartz doubly distilled water (Milli-Q ${ }^{\circledR}$ system, Millipore Corporation, USA) were used throughout the study. ICP-AES exhibits a high degree of linear dynamic range, so in order to obtain more precise calibration curves, multi-point standardization was carried out using $0.5 \mathrm{M} \mathrm{HNO}_{3}$ as a lower standard and 0.05-1000 $\mathrm{mg} / \mathrm{L}$ of the corresponding elemental standard as the higher standard for each line after proper peak search.

\section{Methods}

A series of Pr solutions (commercially available standard reference material elemental solution from E-Merck, Darmstadt, Germany) of varying concentrations (between $0.05 \mathrm{mg} / \mathrm{L}$ to $1000 \mathrm{mg} / \mathrm{L}$ ) were prepared and fed into the argon plasma. The spectral interference of Pr was monitored by observing the contribution in the different channels of the specified analytes. For each analyte, the least interfered analytical lines were identified and the correction factor was evaluated. The tolerance levels of Pr on these lines were also evaluated. The analytical performance of the detection limits, sensitivity, and linear dynamic range were studied for all of the analytical lines.

TABLE I

Specifications and Operating Conditions of ICP-AES

\begin{tabular}{ll}
\hline \multicolumn{2}{l}{ Instrumental Specification for FHS12 ICP-AES } \\
\hline Optical design & Paschen-Runge mounting, Circular design \\
Focal length & $750 \mathrm{~mm}$ \\
Grating & Holographic \\
Groove density & 1800 grooves/mm (1), 3600 grooves/mm (2) \\
Wavelength range & $130-800 \mathrm{~nm}$ \\
Entrance slit width & 15 microns \\
Resolution (FWHM) & $0.01 \mathrm{~nm}$ from $130-450 \mathrm{~nm}$ \\
& $0.02 \mathrm{~nm}$ from $450-800 \mathrm{~nm}$ \\
Thermal regulation & Controlled to $30 \pm 1{ }^{\circ} \mathrm{C}$ \\
Frequency & $27.12 \mathrm{MHz}$ \\
Pump & Dual channel peristaltic pump \\
Detector & Linear arrays of CCD (3648 pixels/array) \\
Nebulizer & Concentric nebulizer with cyclonic spray \\
& chamber \\
ICP torch & Demountable, radial viewing \\
\hline Operating Condition & \\
\hline Coolant flow & $16 \mathrm{~L} / \mathrm{min}$ \\
Auxiliary flow & $0.6 \mathrm{~L} / \mathrm{min}$ \\
Total measurement time & $28 \mathrm{~s}$ \\
Pump speed & $30 \mathrm{Rpm}$ \\
RF power output & $1.2 \mathrm{~kW}$ \\
Input power & $230 \mathrm{~V}$ AC \\
\hline
\end{tabular}

Since the correction factor arising due to the spectral interference is a function of the concentration of the interfering element (Pr), an ICP-AES-based method was also developed for the simultaneous determination of Pr along with the analytes. The analytical performance, including detection limits, sensitivity, linear dynamic range, etc., was evaluated for the identified analytical lines of $\mathrm{Pr}$.

Synthetic samples were used to validate the methodology of direct trace level determination of these analytes in a $\operatorname{Pr}$ matrix without using any chemical separation. The method was also compared with some existing analytical techniques used for trace level determination of these analytes. For common analytes (except for Ag), the d.c. arc carrier distillation technique was used, while for rare earth elements ion chromatography was used for comparison purposes. Ag being added to the samples in the form of $\mathrm{AgCl}$ in the d.c. arc carrier distillation technique, an independent atomic absorption spectroscopy technique was used to compare the results obtained with the newly developed method.

\section{RESULTS AND DISCUSSION}

\section{Simultaneous Determination of the Interfering Element: Pr}

For quantification of the spectral interference, a correction factor needs to be evaluated for the analytical line under investigation. It was observed that the contribution from $\operatorname{Pr}$ on different analytes depends on the Pr concentration 
level in the sample. Therefore, it is required to determine the Pr concentration precisely to evaluate the correct contribution from Pr. In this study, an ICP-AES-based method was developed for the simultaneous determination of $\mathrm{Pr}$ along with the analytes. Since $\mathrm{Pr}$ is a rare earth with line-rich emission spectra, all lines cannot be considered as the analytical line. For the present investigation, four different lines $(411.846 \mathrm{~nm}, 414.311 \mathrm{~nm}$, $417.939 \mathrm{~nm}$, and $422.535 \mathrm{~nm}$ ) were chosen. The detection limit of $\mathrm{Pr}$ using these lines was found to follow the trend: $414.311 \mathrm{~nm}<$ $411.846 \mathrm{~nm} \sim 422.535 \mathrm{~nm}<$ $417.939 \mathrm{~nm}$, while the sensitivity followed the order: $414.311 \mathrm{~nm}>$ $417.939 \mathrm{~nm}>411.846 \mathrm{~nm}>$ $422.535 \mathrm{~nm}$. In case of $\mathrm{Pr}$, the most sensitive line of $414.311 \mathrm{~nm}$ was found to have the lowest detection limit. The slope of the calibration curves was considered as the sensitivity of the analytical lines, whereas the detection limits were calculated as the concentration equivalent to the intensity of blank $(<x\rangle)+5$ times of the relative standard deviation values for blank $(5 \sigma)$. For the analysis of each sample, 10 replicate measurements were carried out, while for the determination of the detection limits and sensitivity, 25 replicate measurements were taken into account.

Synthetic samples containing $\mathrm{Pr}$ in the concentration range of 0.05 $\mathrm{mg} / \mathrm{L}$ - $1000 \mathrm{mg} / \mathrm{L}$ were analyzed using these analytical lines. The analytical results shown in Table II revealed that all four lines can be used for the determination of Pr up to $1000 \mathrm{mg} / \mathrm{L}$, beyond which the experiment was not carried out because of the choking problem in the nebulizer system.

\section{Spectral Interference of Pr on the Analytes}

Due to the advancement in the detector system from a photomultiplier tube (PMT) to a capacitively coupled device (CCD), not only the overall analytical performance is improved, but the CCD-based system also gives an opportunity to choose additional analytical lines of the analytes. This factor is very important in studying spectral interference. In the case when the least interfered analytical line showed the best analytical performance, the situation is simpler. If the best performed analytical line shows significant spectral interference, alternative analytical lines should be

Table II

Determination of Pr by ICP-AES

\begin{tabular}{lllll}
\hline $\operatorname{Pr}(\mathrm{mg} / \mathrm{L})$ & $\begin{array}{c}411.846 \mathrm{~nm} \\
(\mathrm{mg} / \mathrm{L})\end{array}$ & $\begin{array}{c}414.311 \mathrm{~nm} \\
(\mathrm{mg} / \mathrm{L})\end{array}$ & $\begin{array}{c}417.939 \mathrm{~nm} \\
(\mathrm{mg} / \mathrm{L})\end{array}$ & $\begin{array}{c}422.535 \mathrm{~nm} \\
(\mathrm{mg} / \mathrm{L})\end{array}$ \\
\hline 1 & $0.94 \pm 0.03$ & $0.96 \pm 0.04$ & $0.97 \pm 0.05$ & $0.96 \pm 0.04$ \\
5 & $5.0 \pm 0.3$ & $4.8 \pm 0.4$ & $5.1 \pm 0.4$ & $5.0 \pm 0.2$ \\
10 & $10.3 \pm 0.8$ & $9.4 \pm 0.6$ & $9.8 \pm 0.6$ & $9.7 \pm 0.5$ \\
20 & $19.1 \pm 0.8$ & $19.4 \pm 0.8$ & $20.8 \pm 0.6$ & $20.7 \pm 0.6$ \\
50 & $51.8 \pm 1.8$ & $49.5 \pm 1.2$ & $48.7 \pm 1.2$ & $50.8 \pm 1.0$ \\
100 & $99.1 \pm 2.0$ & $102.3 \pm 1.9$ & $100.3 \pm 2.0$ & $98.6 \pm 1.8$ \\
500 & $498 \pm 3$ & $503 \pm 4$ & $496 \pm 5$ & $504 \pm 4$ \\
1000 & $1009 \pm 10$ & $997 \pm 8$ & $995 \pm 7$ & $1002 \pm 6$ \\
D.L. (mg/L) & 0.030 & 0.019 & 0.038 & 0.034 \\
Sensitivity & & & & 2983 \\
(counts/mg/L) & 3257 & 4095 & 3605 & \\
Linear Dynamic & & & & \\
Range (mg/L) & $0.03-1000$ & $0.019-1000$ & $0.04-1000$ & $0.0002-1000$ \\
\hline
\end{tabular}


TABLE III

Spectral Interference of $\mathrm{Pr}$ on $\mathrm{Bi}, \mathrm{Cu}, \mathrm{Li}, \mathrm{Mg}, \mathrm{Mn}, \mathrm{Na}, \mathrm{Cd}, \mathrm{Sr}$, and $\mathrm{Zn}$

\begin{tabular}{|c|c|c|c|c|c|c|c|c|c|}
\hline $\begin{array}{c}\text { Ele- } \\
\text { ments }\end{array}$ & $\begin{array}{l}\text { Analytical } \\
\text { Lines } \\
\text { (nm) }\end{array}$ & $\begin{array}{l}\text { Contribution } \\
\text { From } 1000 \\
\mathrm{mg} / \mathrm{L} \text { of } \mathrm{Pr}\end{array}$ & $\begin{array}{l}\text { Correction } \\
\text { Factor }\end{array}$ & $\begin{array}{l}\text { Tolerance } \\
\text { Level } \\
\text { (mg/L) }\end{array}$ & $\begin{array}{l}\text { Ele- } \\
\text { ments }\end{array}$ & $\begin{array}{l}\text { Analytical } \\
\text { Lines } \\
\text { (nm) }\end{array}$ & $\begin{array}{l}\text { Contribution } \\
\text { From } 1000 \\
\mathrm{mg} / \mathrm{L} \text { of } \mathrm{Pr}\end{array}$ & $\begin{array}{l}\text { Correction } \\
\text { Factor }\end{array}$ & $\begin{array}{c}\text { Tolerance } \\
\text { Level } \\
(\mathrm{mg} / \mathrm{L})\end{array}$ \\
\hline \multirow[t]{5}{*}{$\mathrm{Bi}$} & 223.061 & 3.335 & $3.3 \times 10^{-3}$ & 50 & \multirow[t]{5}{*}{ Mn } & 257.611 & $*$ & - & 1000 \\
\hline & 190.241 & 8.126 & $8.1 \times 10^{-3}$ & 100 & & 259.373 & * & - & 1000 \\
\hline & 306.772 & $*$ & - & 1000 & & 260.569 & 0.102 & $1.0 \times 10^{-4}$ & 500 \\
\hline & 223.061 & 8.794 & $8.8 \times 10^{-3}$ & 200 & & 294.921 & 0.277 & $2.7 \times 10^{-4}$ & 200 \\
\hline & 206.17 & 4.551 & $4.6 \times 10^{-3}$ & 100 & & 403.076 & 1.825 & $1.8 \times 10^{-3}$ & 50 \\
\hline \multirow[t]{5}{*}{$\mathrm{Cu}$} & 324.754 & 0.263 & $2.6 \times 10^{-4}$ & 200 & \multirow[t]{4}{*}{$\mathrm{Na}$} & 589.592 & $*$ & - & 1000 \\
\hline & 327.396 & $*$ & - & 1000 & & 588.995 & $*$ & - & 1000 \\
\hline & 224.7 & 0.735 & $7.3 \times 10^{-4}$ & 50 & & 330.237 & \# & Rejected & 10 \\
\hline & 219.226 & 1.465 & $1.5 \times 10^{-3}$ & 50 & & 330.298 & $\#$ & Rejected & 50 \\
\hline & 219.958 & 0.768 & $7.7 \times 10^{-4}$ & 50 & \multirow[t]{4}{*}{$\mathrm{Cd}$} & 214.438 & 0.142 & $1.4 \times 10^{-4}$ & 500 \\
\hline \multirow[t]{4}{*}{$\mathrm{Li}$} & 670.780 & $*$ & - & 1000 & & 226.502 & $*$ & - & 1000 \\
\hline & 460.289 & 11.46 & $1.1 \times 10^{-2}$ & 10 & & 228.802 & 0.757 & $7.6 \times 10^{-4}$ & 50 \\
\hline & 323.261 & 6.14 & $6.1 \times 10^{-3}$ & 10 & & 361.051 & 10.11 & $1.0 \times 10^{-2}$ & 10 \\
\hline & 274.118 & 11.83 & $1.1 \times 10^{-2}$ & 50 & $\mathrm{Sr}$ & 407.771 & $*$ & - & 1000 \\
\hline \multirow[t]{6}{*}{$\mathrm{Mg}$} & 279.553 & $*$ & - & 1000 & & 421.552 & $*$ & - & 1000 \\
\hline & 280.27 & $*$ & - & 1000 & \multirow{5}{*}{$\mathrm{Zn}$} & 460.733 & 1.107 & $1.1 \times 10^{-3}$ & 50 \\
\hline & 285.213 & 0.134 & $1.3 \times 10^{-4}$ & 500 & & 213.856 & * & - & 1000 \\
\hline & 279.079 & 1.403 & $1.4 \times 10^{-3}$ & 200 & & 206.2 & 1.516 & $1.5 \times 10^{-3}$ & 100 \\
\hline & 202.647 & 2.932 & $2.9 \times 10^{-3}$ & 10 & & 202.613 & 0.252 & $2.5 \times 10^{-4}$ & 200 \\
\hline & & & & & & 334.502 & \# & Rejected & 5 \\
\hline
\end{tabular}

\#Significant Interference. *No Interference.

Table IV

Analytical Performance of Bi, Cu, Li, Mg, Mn, Na, Cd, Sr and $\mathrm{Zn}$ in the Presence of Pr

\begin{tabular}{|c|c|c|c|c|c|c|c|c|c|c|c|}
\hline $\begin{array}{c}\text { Ele- } \\
\text { ments }\end{array}$ & $\begin{array}{l}\text { Analytical } \\
\text { Lines } \\
\text { (nm) }\end{array}$ & $\begin{array}{c}\text { D.L. } \\
(\mathrm{mg} / \mathrm{L})\end{array}$ & $\begin{array}{c}\text { Sensitivity } \\
\text { (counts/ } \\
\text { mg/L) }\end{array}$ & $\begin{array}{c}\text { Linear } \\
\text { Dynamic } \\
\text { Range }(\mathrm{mg} / \mathrm{L})\end{array}$ & $\begin{array}{c}\text { RSD } \\
(\%)\end{array}$ & $\begin{array}{l}\text { Ele- } \\
\text { ments }\end{array}$ & $\begin{array}{l}\text { Analytical } \\
\text { Lines } \\
\text { (nm) }\end{array}$ & $\begin{array}{c}\text { D.L. } \\
(\mathrm{mg} / \mathrm{L})\end{array}$ & $\begin{array}{c}\text { Sensitivity } \\
\text { (counts/ } \\
\mathrm{mg} / \mathrm{L})\end{array}$ & $\begin{array}{c}\text { Linear } \\
\text { Dynamic } \\
\text { Range }(\mathrm{mg} / \mathrm{L})\end{array}$ & $\begin{array}{l}\text { RSD } \\
(\%)\end{array}$ \\
\hline \multirow[t]{5}{*}{$\mathrm{Bi}$} & 190.241 & 1.29 & 39 & $1.29-800$ & 3.2 & \multirow[t]{5}{*}{ Mn } & 257.611 & 0.002 & 12854 & $0.002-1000$ & 2.1 \\
\hline & 206.17 & 0.44 & 76 & $0.44-950$ & 2.8 & & 259.373 & 0.004 & 10246 & $0.004-1000$ & 1.6 \\
\hline & 222.825 & 1.45 & 48 & $1.45-950$ & 2.6 & & 260.569 & 0.01 & 5858 & $0.01-950$ & 2.5 \\
\hline & 223.061 & 0.30 & 346 & $0.30-1000$ & 2.3 & & 294.921 & 0.04 & 1832 & $0.04-900$ & 3.2 \\
\hline & 306.772 & 0.34 & 1521 & $0.34-1000$ & 1.9 & & 403.076 & 0.002 & 9246 & $0.002-1000$ & 1.5 \\
\hline \multirow[t]{5}{*}{$\mathrm{Cu}$} & 219.226 & 0.12 & 377 & $0.12-950$ & 3.9 & \multirow[t]{4}{*}{$\mathrm{Na}$} & 330.237 & 0.81 & 84.25 & $0.81-750$ & 4.1 \\
\hline & 219.958 & 0.039 & 762 & $0.039-1000$ & 2.7 & & 330.298 & 1.69 & 52 & $1.69-600$ & 3.7 \\
\hline & 224.700 & 0.037 & 1859 & $0.037-850$ & 3.1 & & 588.995 & 0.01 & 53418 & $0.01-1000$ & 1.9 \\
\hline & 324.754 & 0.003 & 52029 & $0.003-1000$ & 1.2 & & 589.592 & 0.01 & 32488 & $0.01-1000$ & 1.5 \\
\hline & 327.396 & 0.003 & 34031 & $0.003-1000$ & 0.95 & \multirow[t]{4}{*}{$\mathrm{Cd}$} & 214.438 & 0.006 & 5244 & $0.006-1000$ & 2.1 \\
\hline \multirow[t]{4}{*}{$\mathrm{Li}$} & 274.118 & 0.81 & 41 & $0.81-800$ & 4.7 & & 226.502 & 0.005 & 11493 & $0.005-1000$ & 2.3 \\
\hline & 323.261 & 0.05 & 199 & $0.05-1000$ & 1.5 & & 228.802 & 0.02 & 1884 & $0.02-950$ & 3.6 \\
\hline & 460.289 & 0.18 & 201 & $0.18-950$ & 3.7 & & 361.051 & 0.17 & 318 & $0.17-500$ & 4.9 \\
\hline & 670.780 & 0.001 & 200525 & $0.001-1000$ & 0.86 & \multirow[t]{3}{*}{ Sr } & 407.771 & 0.0002 & 346709 & $0.0002-1000$ & 0.98 \\
\hline \multirow[t]{6}{*}{$\mathrm{Mg}$} & 202.647 & 0.03 & 495 & $0.03-750$ & 4.6 & & 421.552 & 0.0006 & 262155 & $0.0006-1000$ & 1.1 \\
\hline & 279.079 & 0.23 & 390 & $0.23-800$ & 4.4 & & 460.733 & 0.03 & 2307 & $0.03-980$ & 2.5 \\
\hline & 279.553 & 0.0005 & 65352 & $0.0005-1000$ & 1.1 & \multirow[t]{4}{*}{$\mathrm{Zn}$} & 202.613 & 0.008 & 2058 & $0.008-1000$ & 1.1 \\
\hline & 280.270 & 0.0009 & 48536 & $0.0009-1000$ & 1.2 & & 206.200 & 0.21 & 157 & $0.21-850$ & 4.6 \\
\hline & 285.213 & 0.005 & 15455 & $0.005-1000$ & 1.1 & & 213.856 & 0.001 & 18060 & $0.001-1000$ & 1.5 \\
\hline & & & & & & & 334.502 & 0.12 & 453 & $0.12-900$ & 2.8 \\
\hline
\end{tabular}


B, Ba, Ca, Co, Cr, La, Fe, Pb, Tl, Lu, and Dy

The results of spectral interference of $\mathrm{Pr}$ on $\mathrm{B}, \mathrm{Ba}, \mathrm{Ca}, \mathrm{Co}, \mathrm{Cr}, \mathrm{La}$, $\mathrm{Fe}, \mathrm{Pb}, \mathrm{Tl}, \mathrm{Lu}$, and $\mathrm{Dy}$ are listed in Table V, while the analytical performance of the different analytical lines of these elements is listed in Table VI.

\section{Boron (B)}

For B, four different analytical lines (249.773 nm, $249.677 \mathrm{~nm}$, $182.641 \mathrm{~nm}$, and $208.959 \mathrm{~nm}$ ) were chosen for the spectral interference study. The tolerance level of these lines was found to be $100 \mathrm{mg} / \mathrm{L}$, $200 \mathrm{mg} / \mathrm{L}, 200 \mathrm{mg} / \mathrm{L}$, and $500 \mathrm{mg} / \mathrm{L}$ of $\mathrm{Pr}$, respectively, whereas the lowest contribution from Pr was seen for the $\operatorname{Pr} 208.959 \mathrm{~nm}$ line.
The detection limit for these analytical lines followed the trend of $249.773 \mathrm{~nm} \sim 208.959 \mathrm{~nm}<$ $182.641 \mathrm{~nm}<249.677 \mathrm{~nm}$, while the sensitivity followed the order of $208.959 \mathrm{~nm}>249.773 \mathrm{~nm}>$ $249.677 \mathrm{~nm}>182.641 \mathrm{~nm}$. In view of the above study, the B 208.959 $\mathrm{nm}$ line was found to be the best for the determination of $\mathrm{B}$ in a $\mathrm{Pr}$ matrix.

\section{Barium (Ba)}

Of the three analytical lines for Ba chosen for the present purpose (455.404 nm, $233.527 \mathrm{~nm}$ and $230.424 \mathrm{~nm})$, the Ba $455.404 \mathrm{~nm}$ line showed relatively low interference from $\operatorname{Pr}$ with the tolerance level for $500 \mathrm{mg} / \mathrm{L}$ of $\mathrm{Pr}$, while the Ba $233.527 \mathrm{~nm}$ line showed maximum interference from Pr with tol-

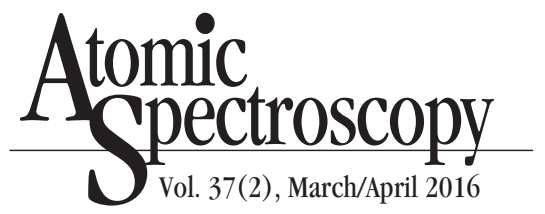

erance level at $10 \mathrm{mg} / \mathrm{L}$. With regard to analytical performance, even though Ba $230.424 \mathrm{~nm}$ showed the lowest detection limit, the sensitivity of this line was poorer in comparison to the $\mathrm{Ba} 455.404 \mathrm{~nm}$ line. Therefore, the $455.404 \mathrm{~nm}$ line of Ba shows to be the best choice in the present situation.

\section{Calcium (Ca)}

The contribution from $1000 \mathrm{mg} / \mathrm{L}$ of $\operatorname{Pr}$ on the different analytical lines of Ca was found to follow the trend of $393.366 \mathrm{~nm}<396.847 \mathrm{~nm}$ $<422.673 \mathrm{~nm}<317.933 \mathrm{~nm}<$ $315.887 \mathrm{~nm}<183.801 \mathrm{~nm}$. Though the Ca $315.887-\mathrm{nm}$ line was found to tolerate $200 \mathrm{mg} / \mathrm{L}$ of $\mathrm{Pr}$, the contribution beyond $200 \mathrm{mg} / \mathrm{L}$ of $\mathrm{Pr}$ was quite large. The detection limit of these analytical lines of $\operatorname{Pr}$

\section{TABLE V}

Spectral Interference of $\mathrm{Pr}$ on $\mathrm{B}, \mathrm{Ba}, \mathrm{Ca}, \mathrm{Co}, \mathrm{Cr}, \mathrm{La}, \mathrm{Fe}, \mathrm{Pb}, \mathrm{Tl}, \mathrm{Lu}$, and $\mathrm{Dy}$

\begin{tabular}{|c|c|c|c|c|c|c|c|c|c|}
\hline $\begin{array}{c}\text { Ele- } \\
\text { ments }\end{array}$ & $\begin{array}{l}\text { Analytical } \\
\text { Lines } \\
(\mathrm{nm})\end{array}$ & $\begin{array}{l}\text { Contribution } \\
\text { From } 1000 \\
\mathrm{mg} / \mathrm{L} \text { of } \mathrm{Pr}\end{array}$ & $\begin{array}{l}\text { Correction } \\
\text { Factor }\end{array}$ & $\begin{array}{c}\text { Tolerance } \\
\text { Level } \\
(\mathrm{mg} / \mathrm{L})\end{array}$ & $\begin{array}{c}\text { Ele- } \\
\text { ments }\end{array}$ & $\begin{array}{l}\text { Analytical } \\
\text { Lines } \\
(\mathrm{nm})\end{array}$ & $\begin{array}{l}\text { Contribution } \\
\text { From } 1000 \\
\mathrm{mg} / \mathrm{L} \text { of } \mathrm{Pr}\end{array}$ & $\begin{array}{c}\text { Correction } \\
\text { Factor }\end{array}$ & $\begin{array}{c}\text { Tolerance } \\
\text { Level } \\
(\mathrm{mg} / \mathrm{L})\end{array}$ \\
\hline \multirow[t]{4}{*}{$\mathrm{B}$} & 249.773 & 0.656 & $6.5 \times 10^{-4}$ & 100 & \multirow[t]{10}{*}{$\mathrm{Fe}$} & 259.941 & 0.323 & $3.2 \times 10^{-4}$ & 200 \\
\hline & 249.677 & 0.352 & $3.5 \times 10^{-4}$ & 200 & & 238.204 & 0.65 & $6.5 \times 10^{-4}$ & 200 \\
\hline & 182.641 & 0.337 & $3.3 \times 10^{-4}$ & 200 & & 239.562 & 0.23 & $2.3 \times 10^{-4}$ & 200 \\
\hline & 208.959 & 0.099 & $9.9 \times 10^{-5}$ & 500 & & 244.451 & 6.124 & $6.1 \times 10^{-3}$ & 10 \\
\hline \multirow[t]{3}{*}{$\mathrm{Ba}$} & 455.404 & 0.183 & $1.8 \times 10^{-4}$ & 500 & & 261.187 & 0.852 & $8.5 \times 10^{-4}$ & 50 \\
\hline & 233.527 & 1.588 & $1.5 \times 10^{-3}$ & 10 & & 262.567 & 2.944 & $2.9 \times 10^{-3}$ & 200 \\
\hline & 230.424 & 0.772 & $7.7 \times 10^{-4}$ & 50 & & 262.829 & 1.887 & $1.8 \times 10^{-3}$ & 200 \\
\hline \multirow[t]{6}{*}{$\mathrm{Ca}$} & 396.847 & 0.351 & $3.5 \times 10^{-4}$ & 10 & & 275.573 & 1.146 & $1.1 \times 10^{-3}$ & 200 \\
\hline & 393.366 & 0.242 & $2.4 \times 10^{-4}$ & 10 & & 241.331 & 2.733 & $2.7 \times 10^{-3}$ & 200 \\
\hline & 317.933 & 1.352 & $1.3 \times 10^{-3}$ & 10 & & 373.486 & 9.342 & $9.3 \times 10^{-3}$ & 5 \\
\hline & 315.887 & 1.922 & $1.9 \times 10^{-3}$ & 200 & \multirow[t]{4}{*}{$\mathrm{Pb}$} & 220.353 & 1.643 & $1.6 \times 10^{-3}$ & 50 \\
\hline & 183.801 & 12.86 & $1.2 \times 10^{-2}$ & 10 & & 405.778 & 17.48 & $1.7 \times 10^{-2}$ & 50 \\
\hline & 422.673 & 0.842 & $8.4 \times 10^{-4}$ & 10 & & 283.305 & 0.623 & $6.2 \times 10^{-4}$ & 200 \\
\hline \multirow[t]{4}{*}{ Co } & 228.616 & 1.242 & $1.2 \times 10^{-3}$ & 50 & & 261.418 & 4.156 & $4.1 \times 10^{-3}$ & 10 \\
\hline & 238.892 & 0.54 & $5.4 \times 10^{-4}$ & 100 & \multirow[t]{2}{*}{$\mathrm{Tl}$} & 190.864 & 0.422 & $4.2 \times 10^{-4}$ & 200 \\
\hline & 230.786 & 1.203 & $1.2 \times 10^{-3}$ & 50 & & 276.787 & $\#$ & Rejected & - \\
\hline & 237.862 & 0.676 & $6.7 \times 10^{-4}$ & 50 & \multirow[t]{4}{*}{$\mathrm{Lu}$} & 261.542 & 0.08 & $8.0 \times 10^{-5}$ & 500 \\
\hline \multirow[t]{5}{*}{$\mathrm{Cr}$} & 267.716 & 0.593 & $5.9 \times 10^{-4}$ & 100 & & 291.139 & 0.455 & $4.5 \times 10^{-4}$ & 200 \\
\hline & 205.618 & 0.07 & $7.0 \times 10^{-5}$ & 500 & & 307.76 & 1.168 & $1.1 \times 10^{-3}$ & 100 \\
\hline & 283.563 & 0.099 & $9.9 \times 10^{-5}$ & 500 & & 219.554 & 0.457 & $4.5 \times 10^{4}$ & 100 \\
\hline & 284.325 & 0.49 & $4.9 \times 10^{-4}$ & 200 & \multirow[t]{5}{*}{ Dy } & 353.170 & 0.398 & $3.9 \times 10^{-4}$ & 200 \\
\hline & 284.984 & 0.622 & $6.2 \times 10^{-4}$ & 50 & & 394.468 & 7.288 & $7.2 \times 10^{-3}$ & 10 \\
\hline \multirow[t]{3}{*}{$\mathrm{La}$} & 408.672 & 9.503 & $9.5 \times 10^{-3}$ & 5 & & 340.780 & 0.546 & $5.4 \times 10^{-4}$ & 200 \\
\hline & 333.749 & 0.493 & $4.9 \times 10^{-4}$ & 100 & & 353.602 & 1.804 & $1.8 \times 10^{-3}$ & 50 \\
\hline & 379.468 & 10.05 & $1.0 \times 10^{-2}$ & 100 & & 364.54 & 8.014 & $8.0 \times 10^{-3}$ & 10 \\
\hline
\end{tabular}

*No Interference. \#Significant Interference. 
followed the same order as the contribution from Pr, while exactly the reverse trend was observed for sensitivity. Based on these studies, the Ca $393.366 \mathrm{~nm}$ line was the best for its trace level determination.

\section{Cobalt (Co)}

For Co, four different analytical lines were chosen for this study (228.616 nm, $238.892 \mathrm{~nm}, 230.786$ $\mathrm{nm}$, and $237.862 \mathrm{~nm})$. The Co $238.892 \mathrm{~nm}$ line showed least interference with a Pr tolerance level at $100 \mathrm{mg} / \mathrm{L}$, while for the rest of the lines the tolerance level for Pr was $50 \mathrm{mg} / \mathrm{L}$. The analytical performance of the Co $238.892 \mathrm{~nm}$ line was found to be the best with a detection limit of $0.032 \mathrm{mg} / \mathrm{L}$ and a sensi- tivity of 2001 counts/mg/L. Thus, it can be chosen for further investigation.

\section{Chromium (Cr)}

For Cr, the $267.716 \mathrm{~nm}, 205.618$ $\mathrm{nm}, 283.563 \mathrm{~nm}, 284.325 \mathrm{~nm}$, and $284.984 \mathrm{~nm}$ lines were chosen to investigate the spectral interference of Pr. It was found that the $\mathrm{Cr}$ $205.618 \mathrm{~nm}$ line was slightly interfered by $1000 \mathrm{mg} / \mathrm{L}$ of $\mathrm{Pr}$, while for the other lines the tolerance level followed the trend of $283.563 \mathrm{~nm}$ $>284.325 \mathrm{~nm}>267.716 \mathrm{~nm}>$ $284.984 \mathrm{~nm}$. The sensitivity of the Cr $205.618 \mathrm{~nm}$ line was the highest with the lowest detection limit (sensitivity 4588 counts/mg/L, detection limit $0.005 \mathrm{mg} / \mathrm{L}$ ). Hence, it is believed to be the best line for the present situation.

\section{Lanthanum (La)}

For La, the analytical performance of the $408.672 \mathrm{~nm}$ and $379.468 \mathrm{~nm}$ lines was moderately better than the $333.749 \mathrm{~nm}$ La line. The former two lines were significantly interfered by Pr and the La $333.749 \mathrm{~nm}$ line appeared to be the best line of choice.

\section{Iron $(\mathrm{Fe})$}

$\mathrm{Fe}$ is one of the transition elements having emission-rich spectra. Out of 10 analytical lines of Fe chosen in the present study, the $259.941 \mathrm{~nm}, 238.204 \mathrm{~nm}, 239.562$

TABLE VI

Analytical Performance of B, Ba, Ca, Co, Cr, La, Fe, Pb, Tl, Lu and Dy Analytes in Presence of Pr

\begin{tabular}{|c|c|c|c|c|c|c|c|c|c|c|c|}
\hline $\begin{array}{l}\text { Ele- } \\
\text { ments }\end{array}$ & $\begin{array}{l}\text { Analytical } \\
\text { Lines } \\
(\mathrm{nm})\end{array}$ & $\begin{array}{c}\text { D.L. } \\
(\mathrm{mg} / \mathrm{L})\end{array}$ & $\begin{array}{c}\text { Sensitivity } \\
\text { (counts/ } \\
\text { mg/L) }\end{array}$ & $\begin{array}{c}\text { Linear } \\
\text { Dynamic } \\
\text { Range }(\mathrm{mg} / \mathrm{L})\end{array}$ & $\begin{array}{c}\text { RSD } \\
(\%)\end{array}$ & $\begin{array}{l}\text { Ele- } \\
\text { ments }\end{array}$ & $\begin{array}{l}\text { Analytical } \\
\text { Lines } \\
(\mathrm{nm})\end{array}$ & $\begin{array}{c}\text { D.L. } \\
(\mathrm{mg} / \mathrm{L})\end{array}$ & $\begin{array}{l}\text { Sensitivity } \\
\text { (counts/ } \\
\text { mg/L) }\end{array}$ & $\begin{array}{c}\text { Linear } \\
\text { Dynamic } \\
\text { Range }(\mathrm{mg} / \mathrm{L})\end{array}$ & $\begin{array}{l}\text { RSD } \\
(\%)\end{array}$ \\
\hline \multirow[t]{4}{*}{ B } & 182.641 & 0.024 & 757 & $0.024-1000$ & 1.2 & \multirow[t]{10}{*}{$\mathrm{Fe}$} & 238.204 & 0.093 & 800 & $0.093-800$ & 2.5 \\
\hline & 208.959 & 0.013 & 4309 & $0.013-1000$ & 1.1 & & 239.562 & 0.032 & 2063 & $0.032-950$ & 2.3 \\
\hline & 249.677 & 0.025 & 1013 & $0.025-975$ & 1.0 & & 241.331 & 0.27 & 229 & $0.27-550$ & 1.6 \\
\hline & 249.773 & 0.013 & 1587 & $0.013-1000$ & 1.1 & & 244.451 & 0.53 & 157 & $0.53-550$ & 1.7 \\
\hline \multirow[t]{3}{*}{$\mathrm{Ba}$} & 230.424 & 0.012 & 793 & $0.012-980$ & 2.1 & & 259.941 & 0.017 & 1689 & $0.017-990$ & 2.1 \\
\hline & 233.527 & 0.091 & 388 & $0.091-790$ & 2.2 & & 261.187 & 0.025 & 943 & $0.025-950$ & 2.0 \\
\hline & 455.404 & 0.028 & 2479 & $0.028-975$ & 1.1 & & 262.567 & 0.29 & 136 & $0.29-750$ & 4.8 \\
\hline \multirow[t]{6}{*}{$\mathrm{Ca}$} & 183.801 & 0.53 & 30 & $0.53-600$ & 3.1 & & 262.829 & 0.37 & 194 & $0.37-650$ & 4.3 \\
\hline & 315.887 & 0.10 & 1114 & $0.10-890$ & 4.2 & & 275.573 & 0.13 & 293 & $0.13-800$ & 4.0 \\
\hline & 317.933 & 0.039 & 3613 & $0.039-780$ & 2.2 & & 373.486 & 0.051 & 2173 & $0.051-950$ & 1.9 \\
\hline & 393.366 & 0.001 & 521209 & $0.001-1000$ & 0.98 & \multirow[t]{3}{*}{$\mathrm{Pb}$} & 220.353 & 0.12 & 274 & $0.12-950$ & 2.8 \\
\hline & 396.847 & 0.002 & 400267 & $0.002-1000$ & 0.90 & & 261.418 & 0.28 & 99 & $0.28-800$ & 1.6 \\
\hline & 422.673 & 0.004 & 25333 & $0.004-1000$ & 1.2 & & 283.305 & 0.068 & 719 & $0.068-1000$ & 1.5 \\
\hline \multirow[t]{4}{*}{ Co } & 228.616 & 0.049 & 826 & $0.049-800$ & 2.2 & & 405.778 & 0.13 & 777 & $0.13-900$ & 1.9 \\
\hline & 230.786 & 0.13 & 658 & $0.13-500$ & 4.8 & \multirow[t]{2}{*}{$\mathrm{Tl}$} & 190.864 & 0.027 & 848 & $0.027-980$ & 1.9 \\
\hline & 237.862 & 0.043 & 1457 & $0.043-970$ & 1.2 & & 276.787 & 0.83 & 27 & $0.83-800$ & 4.3 \\
\hline & 238.892 & 0.032 & 2001 & $0.032-990$ & 2.2 & \multirow[t]{4}{*}{$\mathrm{Lu}$} & 219.554 & 0.045 & 911 & $0.045-800$ & 2.1 \\
\hline \multirow[t]{5}{*}{$\mathrm{Cr}$} & 205.618 & 0.005 & 4588 & $0.005-1000$ & 1.1 & & 261.542 & 0.003 & 7454 & $0.003-1000$ & 0.8 \\
\hline & 267.716 & 0.069 & 659 & $0.069-950$ & 1.7 & & 291.139 & 0.021 & 2427 & $0.021-1000$ & 0.9 \\
\hline & 283.563 & 0.010 & 3603 & $0.010-950$ & 2.2 & & 307.76 & 0.095 & 2856 & $0.095-950$ & 1.1 \\
\hline & 284.325 & 0.079 & 1559 & $0.079-950$ & 3.1 & \multirow[t]{5}{*}{ Dy } & 340.78 & 0.022 & 4299 & $0.022-990$ & 1.7 \\
\hline & 284.984 & 0.018 & 512 & $0.018-700$ & 4.1 & & 353.170 & 0.020 & 14075 & $0.020-1000$ & 1.3 \\
\hline \multirow[t]{3}{*}{$\mathrm{La}$} & 333.749 & 0.017 & 3927 & $0.017-990$ & 2.2 & & 353.602 & 0.053 & 4040 & $0.053-990$ & 1.6 \\
\hline & 379.478 & 0.013 & 5142 & $0.013-1000$ & 3.1 & & 364.540 & 0.032 & 4864 & $0.032-1000$ & 1.6 \\
\hline & 408.672 & 0.012 & 5525 & $0.012-1000$ & 1.5 & & 394.468 & 0.042 & 3884 & $0.042-1000$ & 1.9 \\
\hline
\end{tabular}


$\mathrm{nm}, 262.567 \mathrm{~nm}, 262.829 \mathrm{~nm}$, $275.573 \mathrm{~nm}$, and $241.331 \mathrm{~nm}$ lines were found to tolerate $200 \mathrm{mg} / \mathrm{L}$ of $\mathrm{Pr}$, while for the remaining lines (244.451 nm, $261.187 \mathrm{~nm}, 373.486$ $\mathrm{nm}$ ) the tolerance level was found to be poorer. The sensitivity and the detection limits of the Fe $259.941 \mathrm{~nm}$ and $239.562 \mathrm{~nm}$ lines were found to be better and mutually comparable (sensitivity: 1689 counts/mg/L and 2063 counts/mg/L, detection limit: $0.017 \mathrm{mg} / \mathrm{L}$ and $0.032 \mathrm{mg} / \mathrm{L}$ ). The same was observed in case of the Pr contribution to these Fe lines. Therefore, these two lines appeared to be the best choice for the determination of Fe at trace level in a Pr matrix.

\section{Lead $(\mathrm{Pb})$}

The spectral interference study of $\mathrm{Pr}$ on the $\mathrm{Pb} 220.353 \mathrm{~nm}$, $261.418 \mathrm{~nm}, 283.305 \mathrm{~nm}$, and $405.778 \mathrm{~nm}$ lines revealed that the $283.305 \mathrm{~nm}$ line was least interfered by Pr with a tolerance of 200 $\mathrm{mg} / \mathrm{L}$. The same line also showed the lowest detection limit $(0.068$ $\mathrm{mg} / \mathrm{L}$ ) in a Pr matrix. Based on both factors, the $\mathrm{Pb} 283.305 \mathrm{~nm}$ line should be the best choice for further investigation.

\section{Lutetium (Lu)}

Similarly, of the four Lu analytical lines of $219.554 \mathrm{~nm}, 261.542$ $\mathrm{nm}, 291.139 \mathrm{~nm}$, and $307.760 \mathrm{~nm}$, the least interference was observed for Lu $261.542 \mathrm{~nm}$, with the best analytical performance (detection limit: $0.003 \mathrm{mg} / \mathrm{L}$, sensitivity: 7454 counts/mg/L). Therefore, the Lu $261.542 \mathrm{~nm}$ line can be chosen for the determination of trace level Lu in a $\operatorname{Pr}$ matrix.

\section{Tellurium (Tl)}

In case of $\mathrm{Tl}$, the $276.787 \mathrm{~nm}$ line had severe spectral interference from Pr. Thus, the Tl $190.864 \mathrm{~nm}$ line with a $200 \mathrm{mg} / \mathrm{L}$ Pr tolerance level was chosen for further investigation. The detection limit of the T1 $190.864 \mathrm{~nm}$ line was $0.027 \mathrm{mg} / \mathrm{L}$ with a sensitivity of $\sim 850$ counts/ $\mathrm{mg} / \mathrm{L}$.

\section{Dysprosium (Dy)}

For Dy, the five analytical lines chosen are $340.780 \mathrm{~nm}, 353.170$ $\mathrm{nm}, 353.602 \mathrm{~nm}, 364.540 \mathrm{~nm}$, and $394.468 \mathrm{~nm}$. The contribution from

\section{Atomic Spectroscopy \\ $\bigcup$ Vol. 37(2), March/April 2016}

Pr on these lines followed the trend of $353.170 \mathrm{~nm}<340.780 \mathrm{~nm}<$ $353.602 \mathrm{~nm}<364.540 \mathrm{~nm}<$ $394.468 \mathrm{~nm}$. The least interfered line of $353.170 \mathrm{~nm}$ was found to have the best analytical performance (detection limit: $0.020 \mathrm{mg} / \mathrm{L}$, sensitivity: 4075 counts/mg/L).

\section{$\mathrm{Ag}, \mathrm{Al}, \mathrm{Ga}, \mathrm{In}, \mathrm{Ni}, \mathrm{Gd}$ and $\mathrm{Ce}$}

The spectral interference of $\mathrm{Pr}$ on $\mathrm{Ag}, \mathrm{Al}, \mathrm{Ga}, \mathrm{In}, \mathrm{Ni}, \mathrm{Gd}$, and $\mathrm{Ce}$ (Table VII) revealed that the $\mathrm{Ag}$ $224.641 \mathrm{~nm}, \mathrm{Al} 394.401 \mathrm{~nm}, \mathrm{Ga}$ $417.206 \mathrm{~nm}$, In $451.131 \mathrm{~nm}$, and Ce $448.691 \mathrm{~nm}$ and $393.373 \mathrm{~nm}$ analytical lines were significantly interfered by Pr. Therefore, these lines could not be recommended for the determination these analytes in a $\operatorname{Pr}$ matrix. The minimum interfered lines for $\mathrm{Ag}, \mathrm{Al}, \mathrm{Ga}, \mathrm{In}, \mathrm{Ni}$, $\mathrm{Gd}$, and Ce were found to be $338.289 \mathrm{~nm}, 309.271 \mathrm{~nm}, 294.364$ $\mathrm{nm}, 230.606 \mathrm{~nm}, 221.648 \mathrm{~nm}$, $335.862 \mathrm{~nm}$ and $418.660 \mathrm{~nm}$, respectively. Studies on the analytical performance of different analytical lines of the above-mentioned analytes (Table VIII) revealed that the Ag $328.068 \mathrm{~nm}, \mathrm{Al} 396.152 \mathrm{~nm}$,

TABLE VII

Spectral Interferences of Pr on Ag, Al, Ga, In, Ni, Gd and Ce

\begin{tabular}{|c|c|c|c|c|c|c|c|c|c|}
\hline $\begin{array}{l}\text { Ele- } \\
\text { ments }\end{array}$ & $\begin{array}{c}\text { Analytical } \\
\text { Lines } \\
(\mathrm{nm})\end{array}$ & $\begin{array}{c}\text { Contribution } \\
\text { From } 1000 \\
\mathrm{mg} / \mathrm{L} \text { of } \mathrm{Pr}\end{array}$ & $\begin{array}{l}\text { Correction } \\
\text { Factor }\end{array}$ & $\begin{array}{c}\text { Tolerance } \\
\text { Level } \\
(\mathrm{mg} / \mathrm{L})\end{array}$ & $\begin{array}{l}\text { Ele- } \\
\text { ments }\end{array}$ & $\begin{array}{l}\text { Analytical } \\
\text { Lines } \\
(\mathrm{nm})\end{array}$ & $\begin{array}{l}\text { Contribution } \\
\text { From } 1000 \\
\text { mg/L of } \mathrm{Pr}\end{array}$ & $\begin{array}{c}\text { Correction } \\
\text { Factor }\end{array}$ & $\begin{array}{c}\text { Tolerance } \\
\text { Level } \\
(\mathrm{mg} / \mathrm{L})\end{array}$ \\
\hline \multirow[t]{4}{*}{$\mathrm{Ag}$} & 338.289 & 0.73 & $7.3 \times 10^{-4}$ & 100 & \multirow[t]{6}{*}{$\mathrm{Ni}$} & 231.604 & 0.77 & $7.7 \times 10^{-4}$ & 50 \\
\hline & 328.068 & 1.05 & $1.0 \times 10^{-3}$ & 50 & & 221.648 & 0.48 & $4.8 \times 10^{-4}$ & 200 \\
\hline & 224.641 & \# & Rejected & - & & 232.003 & 3.15 & $3.1 \times 10^{-3}$ & 10 \\
\hline & 243.779 & 1.77 & $1.7 \times 10^{-3}$ & 200 & & 227.021 & 1.24 & $1.2 \times 10^{-3}$ & 100 \\
\hline \multirow[t]{4}{*}{$\mathrm{Al}$} & 396.152 & 7.30 & $7.3 \times 10^{-3}$ & 10 & & 300.249 & 2.42 & $2.4 \times 10^{-3}$ & 50 \\
\hline & 394.401 & \# & Rejected & - & & 341.476 & 0.52 & $5.2 \times 10^{-4}$ & 200 \\
\hline & 308.215 & 1.94 & $1.9 \times 10^{-3}$ & 10 & \multirow[t]{4}{*}{ Gd } & 342.247 & 1.17 & $1.2 \times 10^{-3}$ & 50 \\
\hline & 309.271 & $*$ & & 1000 & & 335.047 & 1.58 & $1.6 \times 10^{-3}$ & 50 \\
\hline \multirow[t]{3}{*}{$\mathrm{Ga}$} & 417.206 & $\#$ & Rejected & - & & 336.223 & 2.93 & $2.9 \times 10^{-3}$ & 10 \\
\hline & 294.364 & 1.13 & $1.1 \times 10^{-3}$ & 10 & & 335.862 & 1.10 & $1.1 \times 10^{-3}$ & 10 \\
\hline & 287.424 & 2.68 & $2.7 \times 10^{-3}$ & 200 & \multirow[t]{5}{*}{$\mathrm{Ce}$} & 418.660 & 2.74 & $2.7 \times 10^{-3}$ & 5 \\
\hline \multirow[t]{4}{*}{ In } & 230.606 & 1.24 & $1.2 \times 10^{-3}$ & 50 & & 448.691 & \# & Rejected & - \\
\hline & 325.609 & 1.90 & $1.9 \times 10^{-3}$ & 10 & & 413.765 & 5.31 & $5.3 \times 10^{-3}$ & 10 \\
\hline & 451.131 & \# & Rejected & - & & 413.38 & 16.8 & $1.7 \times 10^{-2}$ & 5 \\
\hline & 303.936 & 1.32 & $1.3 \times 10^{-3}$ & 200 & & 393.373 & \# & Rejected & - \\
\hline
\end{tabular}

*No Interference. \#Significant Interference. 
Ga $417.206 \mathrm{~nm}$, In $325.609 \mathrm{~nm}, \mathrm{Ni}$ $341.476 \mathrm{~nm}, \mathrm{Gd} 335.047 \mathrm{~nm}$, and Ce $417.380 \mathrm{~nm}$ lines showed the best performance in the presence of a Pr matrix. Unfortunately, in this group of analytes the best performed lines are not the least interfered lines from Pr. Therefore, optimization is required to choose the best line of these analytes in the presence of a Pr matrix. The spectral interference as well as the analytical performance of the lines has to be taken into account. For Ag, the $338.289 \mathrm{~nm}$ line showed the least contribution from $\mathrm{Pr}$ with 100 $\mathrm{mg} / \mathrm{L}$ of tolerance and good analytical performance, i.e., $0.018 \mathrm{mg} / \mathrm{L}$ detection limit, 7156 counts/mg/L sensitivity. Hence, this line was found to be suitable. Tables VII and VIII revealed that the $\mathrm{Al} 308.215$ $\mathrm{nm}, \mathrm{Ga} 294.368 \mathrm{~nm}$, In 230.606 nm, Ni 341.476 nm, Gd 342.247 $\mathrm{nm}$, and Ce $418.660 \mathrm{~nm}$ lines were found to be the most suitable lines for these analytes for their determination in a $\operatorname{Pr}$ matrix.

\section{Direct Determination of the Analytes in a Pr Matrix}

The main aim of this study was to develop a methodology for the direct determination of the analytes in the presence of a Pr matrix without any chemical separation. Based on the above studies, the most suitable analytical lines of the analytes were identified. A set of synthetic samples was prepared using commercially available standard reference materials of the individual elemental solutions. Then the samples were fed into the plasma directly without chemical separation and the results were analyzed. The following six synthetic samples were prepared to study the metal concentrations:

1. Synthetic sample 1 (S 1): $0.1 \mathrm{mg} / \mathrm{L}$ of $\mathrm{Bi}, \mathrm{Cu}, \mathrm{Li}, \mathrm{Mg}, \mathrm{Mn}, \mathrm{Na}$, $\mathrm{Cd}, \mathrm{Sr}$, and $\mathrm{Zn}$ in $1000 \mathrm{mg} / \mathrm{L}$ of $\mathrm{Pr}$

2. Synthetic sample 2 (S 2): $1 \mathrm{mg} / \mathrm{L}$ of $\mathrm{Bi}, \mathrm{Cu}, \mathrm{Li}, \mathrm{Mg}, \mathrm{Mn}, \mathrm{Na}$, $\mathrm{Cd}, \mathrm{Sr}$, and $\mathrm{Zn}$ in $1000 \mathrm{mg} / \mathrm{L}$ of $\mathrm{Pr}$

3. Synthetic sample 3 (S 3): $0.3 \mathrm{mg} / \mathrm{L}$ of $\mathrm{B}, \mathrm{Ba}, \mathrm{Ca}, \mathrm{Co}, \mathrm{Cr}, \mathrm{Fe}$, $\mathrm{Pb}, \mathrm{Tl}, \mathrm{La}, \mathrm{Lu}$, and Dy in $1000 \mathrm{mg} / \mathrm{L}$ of $\mathrm{Pr}$
4. Synthetic sample 4 (S 4): $3 \mathrm{mg} / \mathrm{L}$ of $\mathrm{B}, \mathrm{Ba}, \mathrm{Ca}, \mathrm{Co}, \mathrm{Cr}, \mathrm{Fe}, \mathrm{Pb}$, $\mathrm{Tl}, \mathrm{La}, \mathrm{Lu}$, and Dy in $1000 \mathrm{mg} / \mathrm{L}$ of $\operatorname{Pr}$

5. Synthetic sample 5 (S 5): $1 \mathrm{mg} / \mathrm{L}$ of $\mathrm{Ag}, \mathrm{Al}, \mathrm{Ga}$, In, Ni, Gd, and $\mathrm{Ce}$ in $1000 \mathrm{mg} / \mathrm{L}$ of $\mathrm{Pr}$

6. Synthetic sample 6 (S 6): $10 \mathrm{mg} / \mathrm{L}$ of $\mathrm{Ag}, \mathrm{Al}, \mathrm{Ga}$, In, Ni, Gd, and $\mathrm{Ce}$ in $1000 \mathrm{mg} / \mathrm{L}$ of $\mathrm{Pr}$

The results revealed that $\mathrm{Bi}, \mathrm{Cu}$, $\mathrm{Li}, \mathrm{Mg}, \mathrm{Mn}, \mathrm{Na}, \mathrm{Cd}, \mathrm{Sr}$, and $\mathrm{Zn}$ can be determined even at $0.1 \mathrm{mg} / \mathrm{L}$ concentration in the presence of a Pr matrix (1000 mg/L), while B, Ba, $\mathrm{Ca}, \mathrm{Co}, \mathrm{Cr}, \mathrm{Fe}, \mathrm{Pb}, \mathrm{Tl}, \mathrm{La}, \mathrm{Lu}$, and Dy can be determined at the $0.3 \mathrm{mg} / \mathrm{L}$ level without any chemical separation with an RSD $<5 \%$. It also showed that for $\mathrm{Ag}, \mathrm{Al}, \mathrm{Ga}$, $\mathrm{In}, \mathrm{Ni}, \mathrm{Gd}$, and $\mathrm{Ce}, 1 \mathrm{mg} / \mathrm{L}$ can be determined in the presence of $1000 \mathrm{mg} / \mathrm{L}$ of $\mathrm{Pr}$ as the best performed analytical lines were found to have significant spectral interference. The analyses results of the synthetic samples are listed in Tables IX to XI.

TABLE VIII

Analytical Performance of Ag, Al, Ga, In, Ni, Gd, and Ce in the Presence of Pr

\begin{tabular}{|c|c|c|c|c|c|c|c|c|c|c|c|}
\hline $\begin{array}{l}\text { Ele- } \\
\text { ments }\end{array}$ & $\begin{array}{l}\text { Analytical } \\
\text { ts Lines } \\
(\mathrm{nm})\end{array}$ & $\begin{array}{c}\text { D.L. } \\
(\mathrm{mg} / \mathrm{L})\end{array}$ & $\begin{array}{l}\text { Sensitivity } \\
\text { (counts/ } \\
\text { mg/L) }\end{array}$ & $\begin{array}{c}\text { Linear } \\
\text { Dynamic } \\
\text { Range }(\mathrm{mg} / \mathrm{L})\end{array}$ & $\begin{array}{l}\text { RSD } \\
(\%)\end{array}$ & $\begin{array}{l}\text { Ele- } \\
\text { ments }\end{array}$ & $\begin{array}{l}\text { Analytical } \\
\text { Lines } \\
(\mathrm{nm})\end{array}$ & $\begin{array}{c}\text { D.L. } \\
(\mathrm{mg} / \mathrm{L})\end{array}$ & $\begin{array}{l}\text { Sensitivity } \\
\text { (counts/ } \\
\text { mg/L) }\end{array}$ & $\begin{array}{c}\text { Linear } \\
\text { Dynamic } \\
\text { Range }(\mathrm{mg} / \mathrm{L})\end{array}$ & $\begin{array}{l}\text { RSD } \\
(\%)\end{array}$ \\
\hline \multirow[t]{4}{*}{$\mathrm{Ag}$} & 224.641 & 1.55 & 38 & $1.55-700$ & 5.0 & \multirow[t]{6}{*}{$\mathrm{Ni}$} & 221.648 & 0.13 & 848 & $0.13-780$ & 3.1 \\
\hline & 243.779 & 0.22 & 346 & $0.22-950$ & 4.0 & & 227.021 & 0.046 & 154 & $0.046-950$ & 2.9 \\
\hline & 328.068 & 0.012 & 13737 & $0.012-1000$ & 0.5 & & 231.604 & 0.014 & 853 & $0.014-1000$ & 2.6 \\
\hline & 338.289 & 0.018 & 7156 & $0.018-1000$ & 1.1 & & 232.003 & 0.068 & 703 & $0.068-980$ & 1.5 \\
\hline \multirow[t]{4}{*}{$\mathrm{Al}$} & 308.215 & 0.036 & 1821 & $0.036-950$ & 3.0 & & 300.249 & 0.11 & 642 & $0.11-880$ & 4.2 \\
\hline & 309.271 & 1.89 & 3130 & $1.89-800$ & 2.5 & & 341.476 & 0.012 & 4201 & $0.012-1000$ & 0.97 \\
\hline & 394.401 & 0.016 & 3109 & $0.016-995$ & 1.6 & \multirow[t]{4}{*}{ Gd } & 335.047 & 0.007 & 6474 & $0.007-1000$ & 1.5 \\
\hline & 396.152 & 0.013 & 10037 & $0.031-1000$ & 1.8 & & 335.862 & 0.015 & 3729 & $0.015-1000$ & 1.3 \\
\hline \multirow[t]{3}{*}{$\mathrm{Ga}$} & 287.424 & 0.26 & 182 & $0.26-750$ & 3.6 & & 336.223 & 0.027 & 4423 & $0.027-990$ & 2.2 \\
\hline & 294.364 & 0.032 & 864 & $0.032-700$ & 4.3 & & 342.247 & 0.013 & 5073 & $0.013-750$ & 2.2 \\
\hline & 417.206 & 0.033 & 7693 & $0.033-970$ & 2.2 & \multirow[t]{5}{*}{$\mathrm{Ce}$} & 393.373 & 0.21 & 2216 & $0.21-800$ & 2.3 \\
\hline \multirow[t]{4}{*}{ In } & 230.606 & 0.069 & 577 & $0.069-650$ & 4.9 & & 413.380 & 0.055 & 2313 & $0.055-950$ & 3.9 \\
\hline & 303.936 & 0.10 & 535 & $0.10-700$ & 4.7 & & 413.765 & 0.083 & 2312 & $0.083-975$ & 1.2 \\
\hline & 325.609 & 0.074 & 1489 & $0.074-990$ & 2.3 & & 418.660 & 0.093 & 1899 & $0.093-1000$ & 2.6 \\
\hline & 451.131 & 8.4 & 31 & $8.4-500$ & 4.4 & & 448.691 & 0.85 & 59 & $0.85-700$ & 1.9 \\
\hline
\end{tabular}




\section{Comparison of Present Method} With Other Analytical Method

An attempt was also made to compare the analytical results of the synthetic samples of the present methodology with that of other analytical methods (see Table XII). The synthetic samples contained $0.5 \mathrm{mg} / \mathrm{L}$ of $\mathrm{Bi}, \mathrm{Cu}, \mathrm{Li}$,
$\mathrm{Mg}, \mathrm{Mn}, \mathrm{Na}, \mathrm{Cd}, \mathrm{Sr}, \mathrm{Zn}, \mathrm{B}, \mathrm{Ba}, \mathrm{Ca}$, $\mathrm{Co}, \mathrm{Cr}, \mathrm{Fe}, \mathrm{Pb}, \mathrm{Tl}, \mathrm{La}, \mathrm{Lu}$, and Dy; $1.5 \mathrm{mg} / \mathrm{L}$ concentration of $\mathrm{Ag}, \mathrm{Al}$, $\mathrm{Ga}, \mathrm{In}, \mathrm{Ni}, \mathrm{Gd}$, and Ce in $1000 \mathrm{mg} / \mathrm{L}$ of Pr matrix. The synthetic sample was directly fed to the plasma for analysis without chemical separation. The results were corrected for spectral interference of Pr using the

\section{TABLE IX}

Analysis of Bi, Cu, Li, Mg, Mn, Na, Cd, Sr and Zn in Pr Matrix Using Synthetic Samples Prepared From Commercially Available Standard Reference Materials of Individual Solutions

\begin{tabular}{cc|cc|cc}
\hline & \multicolumn{2}{|c|}{ S1 } & \multicolumn{2}{c}{ S2 } \\
\hline $\begin{array}{c}\text { Ele- } \\
\text { ments }\end{array}$ & $\begin{array}{c}\text { Analytical } \\
\text { Lines } \\
(\mathrm{nm})\end{array}$ & $\begin{array}{c}\text { Actual } \\
\text { Conc. } \\
(\mathrm{mg} / \mathrm{L})\end{array}$ & $\begin{array}{c}\text { Amount } \\
\text { After Incorporating } \\
\text { Correction Factor } \\
(\mathrm{mg} / \mathrm{L})\end{array}$ & $\begin{array}{c}\text { Actual } \\
\text { Conc. } \\
(\mathrm{mg} / \mathrm{L})\end{array}$ & $\begin{array}{c}\text { Amount } \\
\text { After Incorporating } \\
\text { Correction Factor } \\
(\mathrm{mg} / \mathrm{L})\end{array}$ \\
\hline $\mathrm{Bi}$ & 306.772 & 0.10 & $0.12 \pm 0.03$ & 1.0 & $1.02 \pm 0.04$ \\
$\mathrm{Cu}$ & 327.396 & 0.10 & $0.97 \pm 0.01$ & 1.0 & $0.99 \pm 0.05$ \\
$\mathrm{Li}$ & 670.78 & 0.10 & $0.99 \pm 0.03$ & 1.0 & $0.97 \pm 0.05$ \\
$\mathrm{Mg}$ & 279.553 & 0.10 & $0.10 \pm 0.02$ & 1.0 & $1.06 \pm 0.04$ \\
$\mathrm{Mn}$ & 280.27 & 0.10 & $0.98 \pm 0.03$ & 1.0 & $1.03 \pm 0.03$ \\
$\mathrm{Na}$ & 588.995 & 0.10 & $0.97 \pm 0.03$ & 1.0 & $0.97 \pm 0.03$ \\
$\mathrm{Cd}$ & 226.502 & 0.10 & $0.11 \pm 0.02$ & 1.0 & $1.00 \pm 0.04$ \\
$\mathrm{Sr}$ & 421.552 & 0.10 & $0.10 \pm 0.02$ & 1.0 & $1.10 \pm 0.07$ \\
$\mathrm{Zn}$ & 407.771 & 0.10 & $0.97 \pm 0.03$ & 1.0 & $0.96 \pm 0.05$ \\
& 213.856 & 0.10 & $0.99 \pm 0.03$ & 1.0 & $1.03 \pm 0.05$ \\
& & \multicolumn{3}{c|}{$0.03 \pm 0.06$} \\
\hline
\end{tabular}

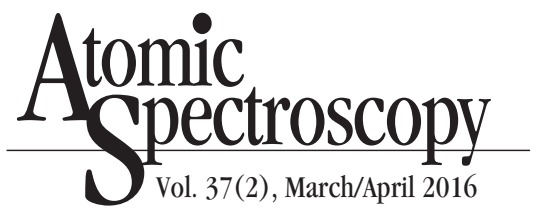

correction factors evaluated previously. The analytical results thus obtained were compared with the existing analytical techniques. For Ag the atomic absorption spectroscopic technique was used for comparison purposes (29). For $\mathrm{Ba}, \mathrm{Bi}$, $\mathrm{Cd}, \mathrm{Cr}, \mathrm{Cu}, \mathrm{Li}, \mathrm{Mg}, \mathrm{Mn}, \mathrm{Na}, \mathrm{Sr}, \mathrm{Zn}$, $\mathrm{Ca}, \mathrm{B} \mathrm{Co}, \mathrm{Fe}, \mathrm{Ga}, \mathrm{Ni}, \mathrm{Tl}$, and $\mathrm{Pb}$ the d.c. arc carrier distillation technique (30) was used. For the rare earth elements (Dy, Ce, Lu, Nd, $\mathrm{La}$, and $\mathrm{Pr}$ ), ion chromatography was employed (31). The results obtained by the present method were found to compare well with the existing methods.

\section{CONCLUSION}

A systematic study was carried out to understand the spectral interference of $\mathrm{Pr}$ on 27 analytes (Ag, Ba, Bi, Cd, Cr, Cu, Dy, Li, Mg, $\mathrm{Mn}, \mathrm{Na}, \mathrm{Nd}, \mathrm{Sr}, \mathrm{Zn}, \mathrm{Ca}, \mathrm{B}, \mathrm{Co}, \mathrm{Fe}$, $\mathrm{Ga}, \mathrm{La}, \mathrm{Ni}, \mathrm{Tl}, \mathrm{Ce}, \mathrm{Pb}, \mathrm{Al}, \mathrm{Gd}$, and In), and its implication on the analysis of these analytes at trace level in the presence of a Pr matrix. Based on the spectral interference and the analytical performance,

TABLE X

Analyses of B, Ba, Ca, Co, Cr, Fe, Pb, Tl, La, Lu and Dy in Pr Matrix Using Synthetic Samples Prepared From Commercially Available Standard Reference Materials of Individual Solutions

\begin{tabular}{|c|c|c|c|c|c|c|c|}
\hline \multirow[b]{2}{*}{$\begin{array}{l}\text { Ele- } \\
\text { ments }\end{array}$} & \multirow[b]{2}{*}{$\begin{array}{l}\text { Analytical } \\
\text { Lines } \\
\text { (nm) }\end{array}$} & \multicolumn{3}{|c|}{$\mathrm{S3}$} & \multicolumn{3}{|c|}{$\mathrm{S} 4$} \\
\hline & & $\begin{array}{l}\text { Actual } \\
\text { Conc. } \\
(\mathrm{mg} / \mathrm{L})\end{array}$ & \multicolumn{2}{|c|}{$\begin{array}{l}\text { Amount } \\
\text { Before After } \\
\text { Incorporating } \\
\text { Correction Factor } \\
(\mathrm{mg} / \mathrm{L}) \quad(\mathrm{mg} / \mathrm{L})\end{array}$} & $\begin{array}{l}\text { Actual } \\
\text { Conc. } \\
\text { (mg/L) }\end{array}$ & $\begin{array}{l}\text { Before } \\
\text { Incor } \\
\text { Correc } \\
(\mathrm{mg} / \mathrm{L})\end{array}$ & $\begin{array}{l}\text { Ant } \\
\text { After } \\
\text { Factor } \\
(\mathrm{mg} / \mathrm{L})\end{array}$ \\
\hline B & 208.959 & 0.3 & $0.40 \pm 0.02$ & $0.31 \pm 0.02$ & 3.0 & $3.16 \pm 0.22$ & $3.07 \pm 0.06$ \\
\hline $\mathrm{Ba}$ & 455.404 & 0.3 & $0.50 \pm 0.03$ & $0.32 \pm 0.01$ & 3.0 & $3.25 \pm 0.15$ & $3.06 \pm 0.07$ \\
\hline $\mathrm{Ca}$ & 393.366 & 0.3 & $0.55 \pm 0.04$ & $0.31 \pm 0.02$ & 3.0 & $3.25 \pm 0.12$ & $3.01 \pm 0.07$ \\
\hline $\mathrm{Co}$ & 238.892 & 0.3 & $0.85 \pm 0.03$ & $0.31 \pm 0.01$ & 3.0 & $3.55 \pm 0.15$ & $3.01 \pm 0.07$ \\
\hline $\mathrm{Cr}$ & 205.618 & 0.3 & $0.41 \pm 0.02$ & $0.33 \pm 0.01$ & 3.0 & $3.11 \pm 0.16$ & $3.04 \pm 0.08$ \\
\hline $\mathrm{Fe}$ & 239.562 & 0.3 & $0.75 \pm 0.06$ & $0.26 \pm 0.03$ & 3.0 & $3.45 \pm 0.19$ & $2.96 \pm 0.08$ \\
\hline & 259.941 & 0.3 & $0.62 \pm 0.03$ & $0.28 \pm 0.01$ & 3.0 & $3.34 \pm 0.14$ & $3.02 \pm 0.07$ \\
\hline $\mathrm{Pb}$ & 283.305 & 0.3 & $0.53 \pm 0.01$ & $0.30 \pm 0.01$ & 3.0 & $3.23 \pm 0.13$ & $3.00 \pm 0.07$ \\
\hline $\mathrm{Tl}$ & 190.864 & 0.3 & $0.90 \pm 0.04$ & $0.28 \pm 0.02$ & 3.0 & $3.50 \pm 0.18$ & $2.88 \pm 0.09$ \\
\hline $\mathrm{La}$ & 333.749 & 0.3 & $0.41 \pm 0.03$ & $0.32 \pm 0.02$ & 3.0 & $3.10 \pm 0.15$ & $3.02 \pm 0.07$ \\
\hline $\mathrm{Lu}$ & 261.542 & 0.3 & $0.73 \pm 0.05$ & $0.31 \pm 0.03$ & 3.0 & $3.40 \pm 0.10$ & $2.98 \pm 0.05$ \\
\hline Dy & 353.17 & 0.3 & $0.72 \pm 0.04$ & $0.33 \pm 0.02$ & 3.0 & $3.41 \pm 0.08$ & $3.02 \pm 0.04$ \\
\hline
\end{tabular}


TABLE XI

Analysis of Ag, Al, Ga, In, Ni, Gd and Ce in Pr Matrix Using Synthetic Samples Prepared From Commercially Available Standard Reference Materials of Individual Solutions

\begin{tabular}{|c|c|c|c|c|c|c|c|}
\hline \multirow{4}{*}{$\begin{array}{c}\text { Ele- } \\
\text { ments }\end{array}$} & \multirow{4}{*}{$\begin{array}{l}\text { Analytical } \\
\text { Lines } \\
\text { (nm) }\end{array}$} & \multicolumn{3}{|c|}{ S5 } & \multicolumn{3}{|c|}{ S6 } \\
\hline & & \multirow{3}{*}{$\begin{array}{l}\text { Actual } \\
\text { Conc. } \\
\text { (mg/L) }\end{array}$} & \multirow{3}{*}{\multicolumn{2}{|c|}{$\begin{array}{l}\text { Amount } \\
\text { Before After } \\
\text { Incorporating } \\
\text { Correction Factor } \\
(\mathrm{mg} / \mathrm{L}) \quad(\mathrm{mg} / \mathrm{L})\end{array}$}} & \multirow{3}{*}{$\begin{array}{l}\text { Actual } \\
\text { Conc. } \\
\text { (mg/L) }\end{array}$} & \multicolumn{2}{|c|}{ Amount } \\
\hline & & & & & & $\begin{array}{l}\text { Before } \\
\text { Inco } \\
\text { Correc }\end{array}$ & $\begin{array}{l}\text { After } \\
\text { rating } \\
\text { on Factor }\end{array}$ \\
\hline & & & & & & $(\mathrm{mg} / \mathrm{L})$ & $(\mathrm{mg} / \mathrm{L})$ \\
\hline Ag & 338.289 & 1.0 & $1.86 \pm 0.06$ & $1.13 \pm 0.04$ & 10.0 & $10.6 \pm 0.4$ & $9.87 \pm 0.08$ \\
\hline $\mathrm{Al}$ & 308.215 & 1.0 & $3.00 \pm 0.08$ & $1.06 \pm 0.04$ & 10.0 & $12.2 \pm 0.3$ & $10.26 \pm 0.14$ \\
\hline Ga & 294.364 & 1.0 & $2.03 \pm 0.05$ & $0.90 \pm 0.02$ & 10.0 & $11.0 \pm 0.4$ & $9.87 \pm 0.21$ \\
\hline In & 230.606 & 1.0 & $2.14 \pm 0.07$ & $0.90 \pm 0.03$ & 10.0 & $11.3 \pm 0.2$ & $10.06 \pm 0.11$ \\
\hline $\mathrm{Ni}$ & 341.476 & 1.0 & $1.51 \pm 0.08$ & $0.99 \pm 0.04$ & 10.0 & $10.1 \pm 0.2$ & $9.58 \pm 0.09$ \\
\hline Gd & 342.247 & 1.0 & $2.22 \pm 0.07$ & $1.05 \pm 0.04$ & 10.0 & $11.0 \pm 0.3$ & $9.83 \pm 0.11$ \\
\hline $\mathrm{Ce}$ & 418.660 & 1.0 & $3.81 \pm 0.07$ & $1.07 \pm 0.04$ & 10.0 & $12.5 \pm 0.4$ & $9.76 \pm 0.12$ \\
\hline
\end{tabular}

the analytical lines of $\mathrm{Ag} 338.289 \mathrm{~nm}$, Al $308.215 \mathrm{~nm}$, Ga $294.361 \mathrm{~nm}$, In $230.606 \mathrm{~nm}$, Ni $341.476 \mathrm{~nm}$, Gd $342.247 \mathrm{~nm}$, Ce $418.660 \mathrm{~nm}$, B $208.959 \mathrm{~nm}, \mathrm{Ba} 455.404 \mathrm{~nm}$, Ca $393.366 \mathrm{~nm}$, Co $238.892 \mathrm{~nm}$, Cr $205.618 \mathrm{~nm}, \mathrm{~Pb} 283.305 \mathrm{~nm}$, T1 $190.864 \mathrm{~nm}, \mathrm{La} 333.749 \mathrm{~nm}$, Lu $261.542 \mathrm{~nm}$, Dy $353.170 \mathrm{~nm}$, Bi $306.772 \mathrm{~nm}, \mathrm{Cu} 327.396 \mathrm{~nm}$, Li $670.780 \mathrm{~nm}$, Mn $259.373 \mathrm{~nm}$, $\mathrm{Na} 588.995 \mathrm{~nm}$, Cd $226.502 \mathrm{~nm}$, and $\mathrm{Zn} 213.856 \mathrm{~nm}$ were found to be suitable for the determination of these analytes in a Pr matrix. For the analytes $\mathrm{Fe}, \mathrm{Mg}$, and $\mathrm{Sr}$, two analytical lines for each (239.562 $\mathrm{nm}$ and $259.941 \mathrm{~nm}$; $279.553 \mathrm{~nm}$ and $280.270 \mathrm{~nm}$; $421.552 \mathrm{~nm}$ and $407.771 \mathrm{~nm}$, respectively) were found to be suitable. A methodology for the direct determination of the analytes in a Pr matrix without any chemical separation was developed, and it revealed that $\mathrm{Bi}, \mathrm{Cu}, \mathrm{Li}, \mathrm{Mg}, \mathrm{Mn}, \mathrm{Na}$, $\mathrm{Cd}, \mathrm{Sr}$, and $\mathrm{Zn}$ can be determined at $0.1 \mathrm{mg} / \mathrm{L}$ and $\mathrm{B}, \mathrm{Ba}, \mathrm{Ca}, \mathrm{Co}, \mathrm{Cr}, \mathrm{Fe}$, $\mathrm{Pb}, \mathrm{Tl}, \mathrm{La}, \mathrm{Lu}$, and Dy can be determined at the $0.3 \mathrm{mg} / \mathrm{L}$ concentration level, while Ag, Al, Ga, In, Ni, $\mathrm{Gd}$, and Ce can be determined at $1 \mathrm{mg} / \mathrm{L}$ concentration. The methodology was validated using synthetic samples, prepared from commercially available standard reference material solution of individual ele- ments, and was also compared with existing analytical techniques. The analytical results were found to be encouraging.

\section{ACKNOWLEDGMENT}

The authors wish to acknowledge the constant support and keen interest in this work of Dr. A. Goswami, Head, Radiochemistry Division, Bhabha Atomic Research Centre, Mumbai, India.

$\overline{\text { Received March 12, } 2015 .}$

\section{REFERENCES}

1. I. Jarvis and K. E. Jarvis, Chem. Geology 95, 1 (1992).

2. P. W. J. M. Boumans, Spectmhim. Acta 358, 57 (1979).

3. S. L. Maxwell, M. A. Bernarda, M. R. Nelson, and L. D. Youmans, Talanta 76, 432 (2008).

4. Z. U. Bae, S. H. Lee, and S. H. Lee, Talanta 44, 37 (1997).

5. J. L. Todolı', L. Gras, V. Hernandis, and J. Mora, J. Anal. At. Spectrom. 17, 142 (2002).

6. V.C. Adya, A. Sengupta, and S.V. Godbole, Atom Spectrosc. 35(1), 25 (2014).

7. A. Sengupta, V.C. Adya, and S.V. Godbole, J. Radioanal. Nucl.
Chem., DOI 10.1007/s10967-0132520-0 (2014).

8. A. Sengupta, B. Rajeswari, R.M. Kadam, and R. Acharya, At. Spectrosc. 32(5), 200 (2011).

9. A. Sengupta, and V.C.Adya, At. Spectrosc. 34(6), 207 (2013).

10. A. Sengupta, and V.C.Adya, J. Radioanal. Nucl. Chem. 299, 2023 (2014).

11. N.K. Porwal, A.A. Argekar, P.J. Purohit, A.G. Page, and M.D. Sastry, Fresenius J. Anal. Chem. 338, 255 (1990).

12. A.G. Page, K.H. Madraswala, S.V. Godbole, M.J. Kulkarni, V.S. Mallapurkar, and B.D. Joshi, Fresenius Z. Anal. Chem. 315, 38 (1983).

13. A.G. Page, S.V. Godbole, S. Deshkar, Y. Babu, and B.D. Joshi, Fresenius J. Anal. Chem. 287, 304 (1977).

14. A.G.I. Dalvi, C.S. Deodhar, T.K. Seshagiri, M.S. Khalap, and B.D. Joshi, Talanta 25, 665 (1978) .

15. B. Rajeswari, B.A. Dhawale, T.R. Bangia, J.N. Mathur, and A.G. Page, J. Radioanal. Nucl.Chem. 254(3), 479 (2002).

16. A.Sengupta, M. J.Kulkarni, and S. V. Godbole, J. Radioanal. Nucl. Chem. 289(3), 961 (2011).

17. A.A. Argekar, M.J. Kulkarni, J.N. Mathur, and A.G. Page, Talanta 56(4), 591 (2002). 


\section{Amic $_{\text {Spectroscopy }}^{\text {tomic) Marcharpil } 2016}$}

TABLE XII

Comparison of Present Methodology

With Existing Analytical Techniques

\begin{tabular}{lccc}
\hline Elements & $\begin{array}{c}\text { Analytical Lines } \\
(\mathrm{nm})\end{array}$ & $\begin{array}{c}\text { Estimated by } \\
\text { Present Method } \\
(\mathrm{mg} / \mathrm{L})\end{array}$ & $\begin{array}{c}\text { Comparison With } \\
\text { Other Method } \\
(\mathrm{mg} / \mathrm{L})\end{array}$ \\
\hline $\mathrm{Ag}$ & 338.289 & $1.52 \pm 0.02$ & $1.46 \pm 0.08^{*}$ \\
$\mathrm{Al}$ & 308.215 & $1.49 \pm 0.03$ & $1.51 \pm 0.06^{* *}$ \\
$\mathrm{Ga}$ & 294.364 & $1.46 \pm 0.05$ & $1.52 \pm 0.08^{* *}$ \\
$\mathrm{In}$ & 230.606 & $1.42 \pm 0.08$ & $1.49 \pm 0.07^{* *}$ \\
$\mathrm{Ni}$ & 341.476 & $1.40 \pm 0.07$ & $1.46 \pm 0.06^{* *}$ \\
$\mathrm{Gd}$ & 342.247 & $1.55 \pm 0.09$ & $1.40 \pm 0.07^{*}$ \\
$\mathrm{Ce}$ & 418.660 & $1.54 \pm 0.08$ & $1.43 \pm 0.09^{*}$ \\
$\mathrm{~B}$ & 208.959 & $0.52 \pm 0.02$ & $0.48 \pm 0.03^{* *}$ \\
$\mathrm{Ba}$ & 455.404 & $0.48 \pm 0.02$ & $0.51 \pm 0.03^{* *}$ \\
$\mathrm{Ca}$ & 393.366 & $0.50 \pm 0.04$ & $0.52 \pm 0.04^{* *}$ \\
$\mathrm{Co}$ & 238.892 & $0.50 \pm 0.04$ & $0.49 \pm 0.04^{* *}$ \\
$\mathrm{Cr}$ & 205.618 & $0.47 \pm 0.03$ & $0.46 \pm 0.04^{* *}$ \\
$\mathrm{Fe}$ & 239.562 & $0.47 \pm 0.02$ & $0.52 \pm 0.03^{* *}$ \\
& 259.941 & $0.51 \pm 0.02$ & $0.54 \pm 0.04^{* *}$ \\
$\mathrm{~Pb}$ & 283.305 & $0.52 \pm 0.03$ & $0.47 \pm 0.03^{* *}$ \\
$\mathrm{Tl}$ & 190.864 & $0.52 \pm 0.03$ & $0.47 \pm 0.05^{* *}$ \\
$\mathrm{La}$ & 333.749 & $0.48 \pm 0.01$ & $0.46 \pm 0.06^{* *}$ \\
$\mathrm{Lu}$ & 261.542 & $0.50 \pm 0.03$ & $0.51 \pm 0.02^{*}$ \\
$\mathrm{Dy}$ & 353.170 & $0.53 \pm 0.04$ & $0.50 \pm 0.05^{* *}$ \\
$\mathrm{Bi}$ & 306.772 & $0.48 \pm 0.03$ & $0.53 \pm 0.04^{* *}$ \\
$\mathrm{Cu}$ & 327.396 & $0.49 \pm 0.02$ & $0.54 \pm 0.06^{* *}$ \\
$\mathrm{Li}$ & 670.780 & $0.52 \pm 0.03$ & $0.46 \pm 0.04^{* *}$ \\
$\mathrm{Mg}$ & 279.553 & $0.52 \pm 0.03$ & $0.47 \pm 0.05^{* *}$ \\
& 280.270 & $0.48 \pm 0.01$ & $0.46 \pm 0.06^{* *}$ \\
$\mathrm{Mn}$ & 259.373 & $0.50 \pm 0.03$ & $0.51 \pm 0.02^{* *}$ \\
$\mathrm{Na}$ & 588.995 & $0.53 \pm 0.04$ & $0.50 \pm 0.05^{* *}$ \\
$\mathrm{Cd}$ & 226.502 & $0.48 \pm 0.03$ & $0.53 \pm 0.04^{* *}$ \\
$\mathrm{Sr}$ & 421.552 & $0.49 \pm 0.02$ & $0.54 \pm 0.06^{* *}$ \\
& 407.771 & $0.52 \pm 0.03$ & $0.46 \pm 0.04^{* *}$ \\
$\mathrm{Zn}$ & 213.856 & $0.48 \pm 0.01$ & $0.46 \pm 0.06^{* *}$ \\
& & &
\end{tabular}

Note: The Pr concentration in the synthetic sample is $1000 \mathrm{mg} / \mathrm{L}$.

\# Analysis by Atomic Absorption Spectroscopy.

*** Analysis by D.C. arc carrier distillation technique.

* Analysis by chromatographic technique.

18. C. Mahan, S. Bonchin, D. Figg, D. Gcrth, and C. Collier, J. Anal. At. Spectrom.15 (8), 929 (2000).

19. S. Marin, S. Cornejo, C. Jara, and N. Duran, Fresenius J. Anal. Chem. 355, 680 (5-6) (1996).

20. E.A. Huff, At. Spectrosc. 42(1-2), 275 (1987).

21. E.A. Huff and D.L. Bowers, Appl. Spectrosc. 43(2), 223 (1989).

22. M.D. Sastry, M.K. Bhide, K. Savitri, Y. Babu, and B.D. Joshi,
Fresenius Z. Anal. Chem. 308, 456 (1981).

23. B.F. Scribner, and H.R. Mullin, J. Res. Natl. Bur. Stds. 37, 379 (1946).

24. P.W.J.M. Boumans, Spectrochim. Acta 438(2), 173 (1988).

25. A. Mazzucotelli, F. de Paz, E. Magi, and R. Frache, Anal. Sci. 8, 189 (1992).

26. E. Kostadinova, L. Aleksieva, S. Velichkov, and N. Daskalova,
Spectrochim. Acta Part B 55, 689 (2000).

27. K-S. Choi, C-H Lee, J-G Kim, W-H Kim, and J-G Kang, Talanta 71, 662 (2007).

28. S. Gu, H. Ying, Z Zhang, Z. Zhuang, P. Yang, X. Wang, B. Huang, and L. Bing, Spectrochim. Acta B 52, 1567 (1997).

29. T. Blazheva, and A. Delijska - Krushevska, Fresenius J. Anal. Chem. 338, 294 (1990).

30. N. Pathak, V.C. Adya, S.K. Thulasidas, A. Sengupta, T.K. Seshagiri, and S.V. Godbole, At. Spectrosc. 35(1), 17 (2014).

31. M.C.Bruzzoniti, E. Mentasti, C. Sarzanini, M. Braglia, G.Cocito, and J. Kraus, Anal. Chim. Acta 332, 49 (1996). 